\title{
A CONCEPTUAL MODEL OF THE ACADEMIC DISCIPLINE NURSING SCIENCE
}

\author{
W.J. Kotze, C. Searle, L.R. Uys
}

At their annual meeting during 1987, the heads of the Departments of Nursing at South African Universities discussed the sub-division of Nursing Science. They identified the following problems in this regard:

(1) There was no consensus amongst nursing leaders about which sub-disciplines make up the academic disciplines of nursing.

(2) This made it difficult to communicate with agencies outside the ursing profession, such as the Committe or University Heads or the Department of Education and Training in a way that lent legitimacy to the discipline.

(3) Some of the titles traditionally used in describing certain sub-disciplines were conceptually unsatisfactory.

(4) In the present climate of rationalisation in academic institutions some of the traditional titles lent themselves to misinterpretation by members of other academic disciplines, and threatened the continued existence of these sub-disciplines as part of nursing science.

A subcommittee was appointed to address these problems and at their 1988 meeting the total group accepted the following model for the discipline of nursing science.

Nursing Science consists of subdisciplines which can be subdivided into three groups; core disciplines (kernvakke), ractice disciplines (praktykkunde vakke), d clinical disciplines (kliniese vakke).

These categories include the following subdisciplines:

Core disciplines: Philosophy and History of Nursing (Filosofie en Geskiedenis van Verpleging)

Practice disciplines: Science of Nursing Practice

(Verplegingsprak-

tykkunde)

Nursing Didactics

(Verplegingsdidaktiek)

Clinical disciplines: Fundamental Nursing

Science

General Nursing

Science

Psychiatric Nursing

Science

Midwifery

Community Nursing

Science

\section{Opsomming}

Die Komitee van Universiteits -

verpleeghoofde het vroeg in 1988 'n konseptuele model aanvaar wat die vakwelenskap verpleegkunde se deeldissiplines identifiseer en heskryf.

Die vakwetensk ap is verdeel in drie

groepe deeldissiplines, naam/ik

kernvakke, praktykkunde vakke en

kliniese vakke. Die kernvakke sluit in

die Geskiedenis en filosofie van

Verpleging. en die praktykkunde vakke sluih in die Verplegingsdidaktiek

(voorheen bekend as verpleegonderwys) en die Verplegingspraktykkunde

(voorheen bekend as verpleeg.

administrasie). Die kliniese vakke sluit

in Fundamentele Verpleegkunde.

Algemene Verpleegkunde, Psigiatriese

Verpleegkunde, Gemeenskaps-

verpleegkunde, en Verloskunde. Die

konteks waarin verpleging plaasvind is geidentifiseer as die leeftydsmodi en die onvattende gesondheidstenadering.

Die konseptuele model word

diagramaties geillustreer.
A diagram was prepared to illustrate the composition of the discipline of Nursing Science. A prism forms the central figure of this diagram. The floor of this prism is made up of Fundamental Nursing, since al other clinical sub-disciplines are based on this component. The four clinical subdisciplines form the prism in equal parts. The four sides of the prism, which gives it its shape, is the Science of Nursing Practice, or what used to be called nursing administration. The corner pillars of the prism, giving it its stability and height is the Nursing Didactics, or what used to be called nursing education.

In the centre of the prism one finds the core disciplines of Nursing Philosophy and History, which permeates all the other subdisciplines. If you analyse any of them, you will find a philosophy and a history of that sub-discipline.

The whole prism is placed in a sphere or a ball, which represents the context in which nursing takes place. The sphere reminds us that nursing touches all life modes, including all ages, cultures, sexes, etc. and that it takes place in a comprehensive health-care approach.

The basic content-areas of these subdisciplines will have to be identified, described, researched and broadened over

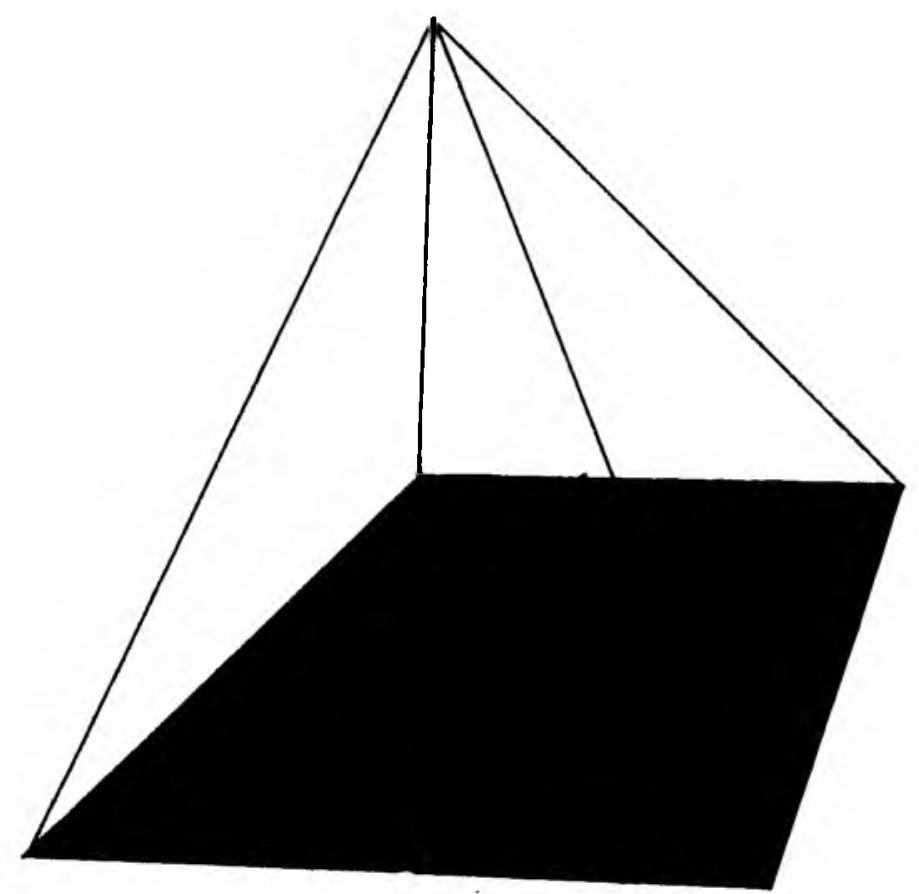

1. Fundamental nursing science: the foundation 


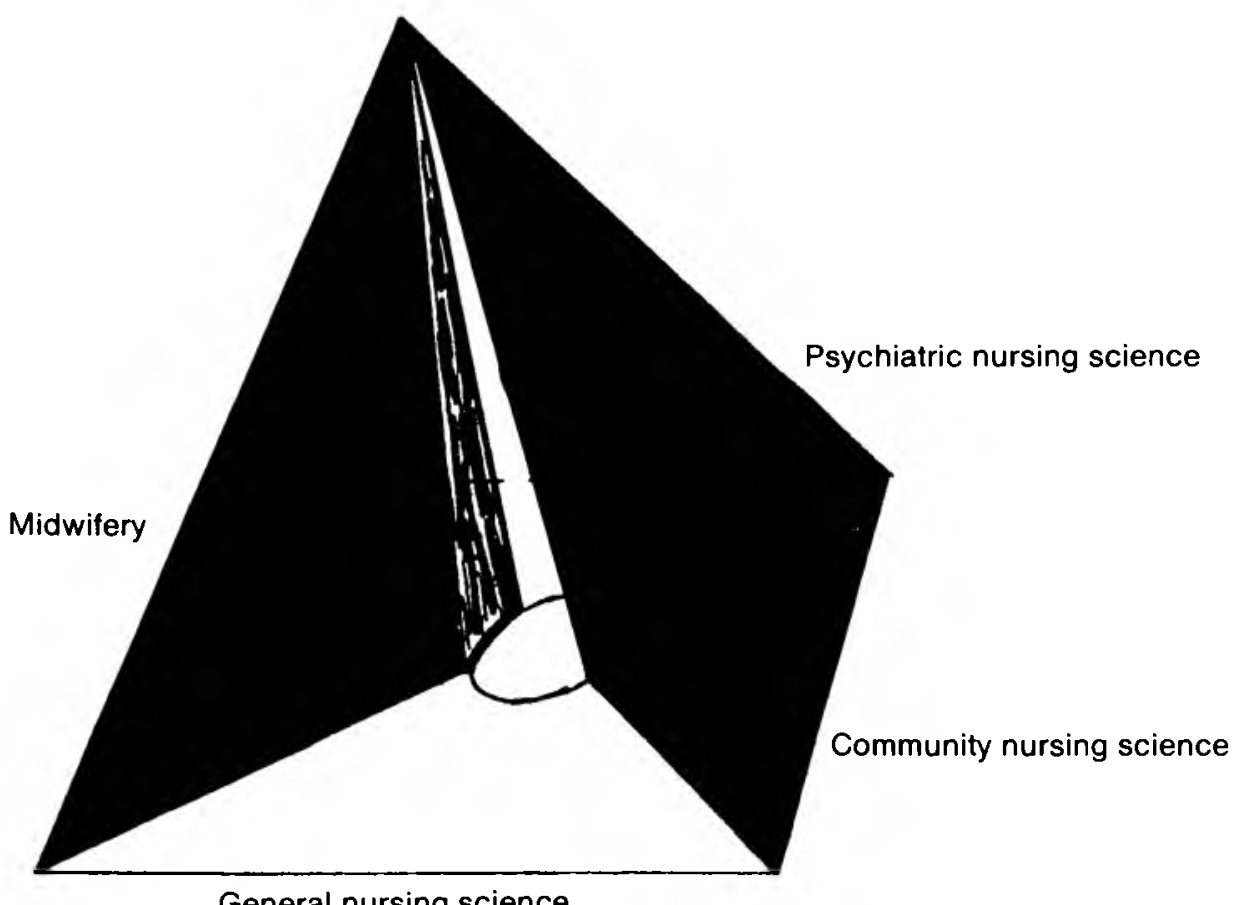

General nursing science

2. Other clinical disciplines

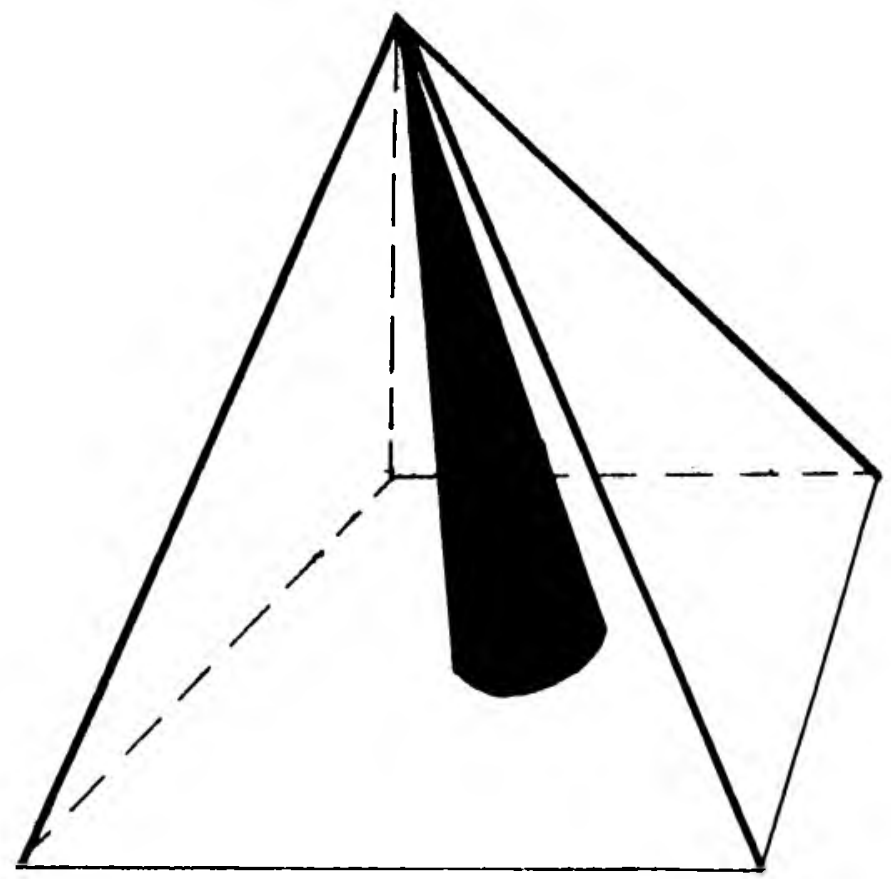

3. The core disciplines: Philosophy and $\mid$ History of Nursing The corner pillars: Nursing Didactics

time. They do not form water-tight compartments, but only represent a conceptual framework for the discipline. At the moment the content of each subdiscipline is seen to include the following:

Philosophy and history of nursing: The history of nursing and all its sub-disciplines.

The influence of world and regional history on nursing.
Science of nursing practice:

The characteristics, philosophy, aims, objectives and structures of a nursing service.

The types, structure, economics, philosophy and aims of the health-care system.

The dynamics of the nursing service and the health service.

The principles and techniques of the planning, maintenance and evaluation of a nursing service on a unit, section, institution, programme, regional or national level.

The legal and professional requirements of nursing practice.

\section{Nursing Didactics:}

The process of professional socialisation in nursing.

The characteristics of the learner, the learning process, the teaching process and the evaluation process in nursing.

The types, structure, economics, philosophy and aims of nursing education systems.

The legal and professional requirements nursing education.

The preparation of nurse-preceptors, role models and teachers.

The administration of nursing education

Fundamental nursing science:

The basic health needs of healthy human beings in all age-groups.

The basic nursing approaches and techniques to address the health needs of individuals, families, groups and communities.

A scientific approach to the practice of nursing.

The legal, professional and philosophical parameters of nursing.

General nursing science:

The history and philosophy of nursing as applied to this sub-discipline.

The health needs of physically ill persons (patients) in all age-groups.

The influences of different patient characteristics on health needs and nursing.

The process and techniques of medical diagnosis and treatment and its influence on nursing.

The nursing approaches and techniques to address these health needs.

The nursing assessment of patients, planning, implementation and evaluation of care.

The structures, philosophies, systems, economics, politics and aims of general health services.

\section{Psychiatric nursing science:}

The history and philosophy of nursing as applied to this sub-discipline.

The health needs of people with psychiatric problems.

The health needs of different patient characteristics on health needs and nursing.

The process of psychiatric diagnosis and treatment and its influence on nursing. The nursing approaches and techniques to address these health needs. 


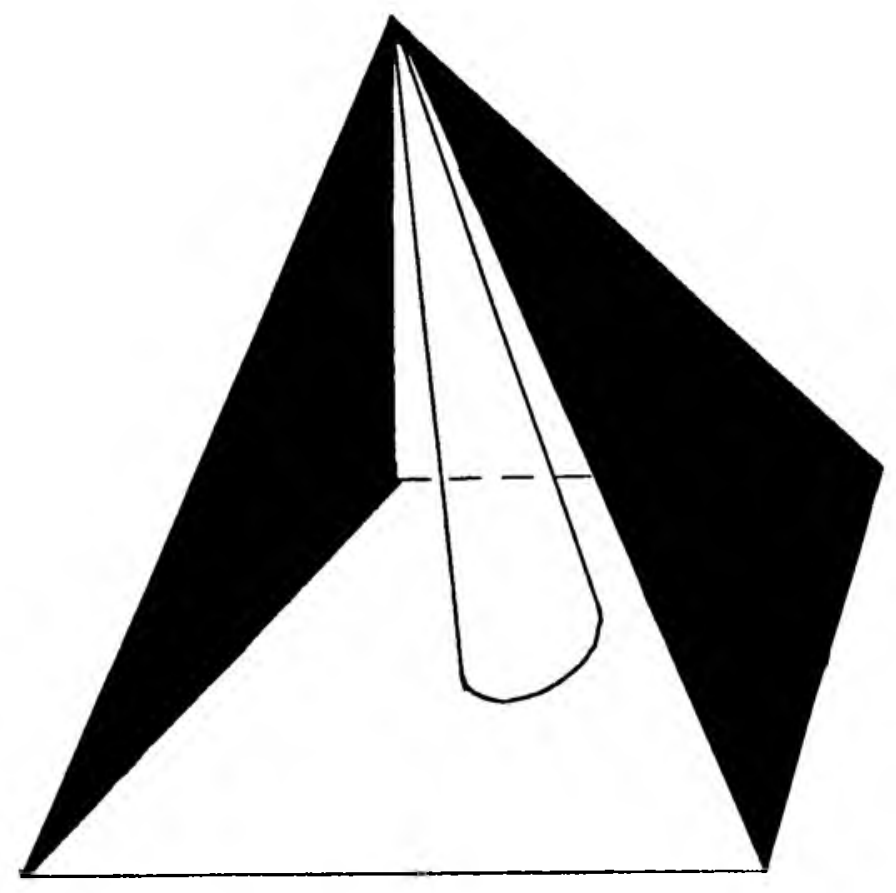

4. The science of nursing practice (only two of the four sides coloured in)
The nursing assessment of patients, planning, implementation and evaluation of care.

The structures, philosophies, systems, economics, politics and aims of psychiatric services.

\section{Midwifery:}

The history and philosophy of nursing as applied to this sub-discipline.

The health needs of women during pregnancy, labour and the puerperium. The health needs of babies from conception to the age of six weeks. The transition of the family through different life stages associated with child-bearing.

The process of medical diagnosis and treatment during pregnancy, labour and the puerperium.

The nursing approaches and techniques to address these health needs.

The nursing assessment, planning, implementation and evaluation of care to the woman and baby.

The structures, philosophies, systems, economics, politics and aims of midwifery services.

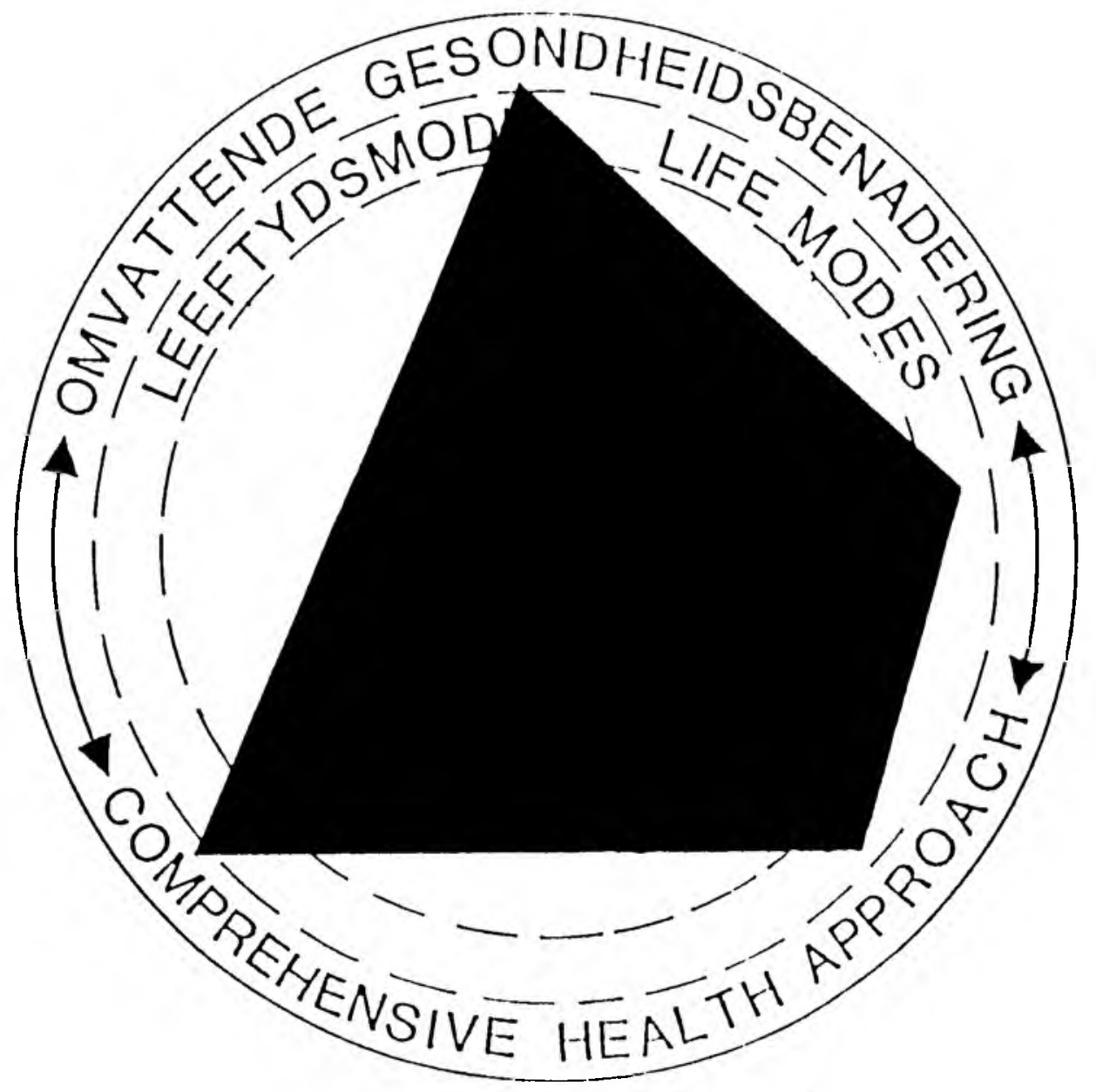




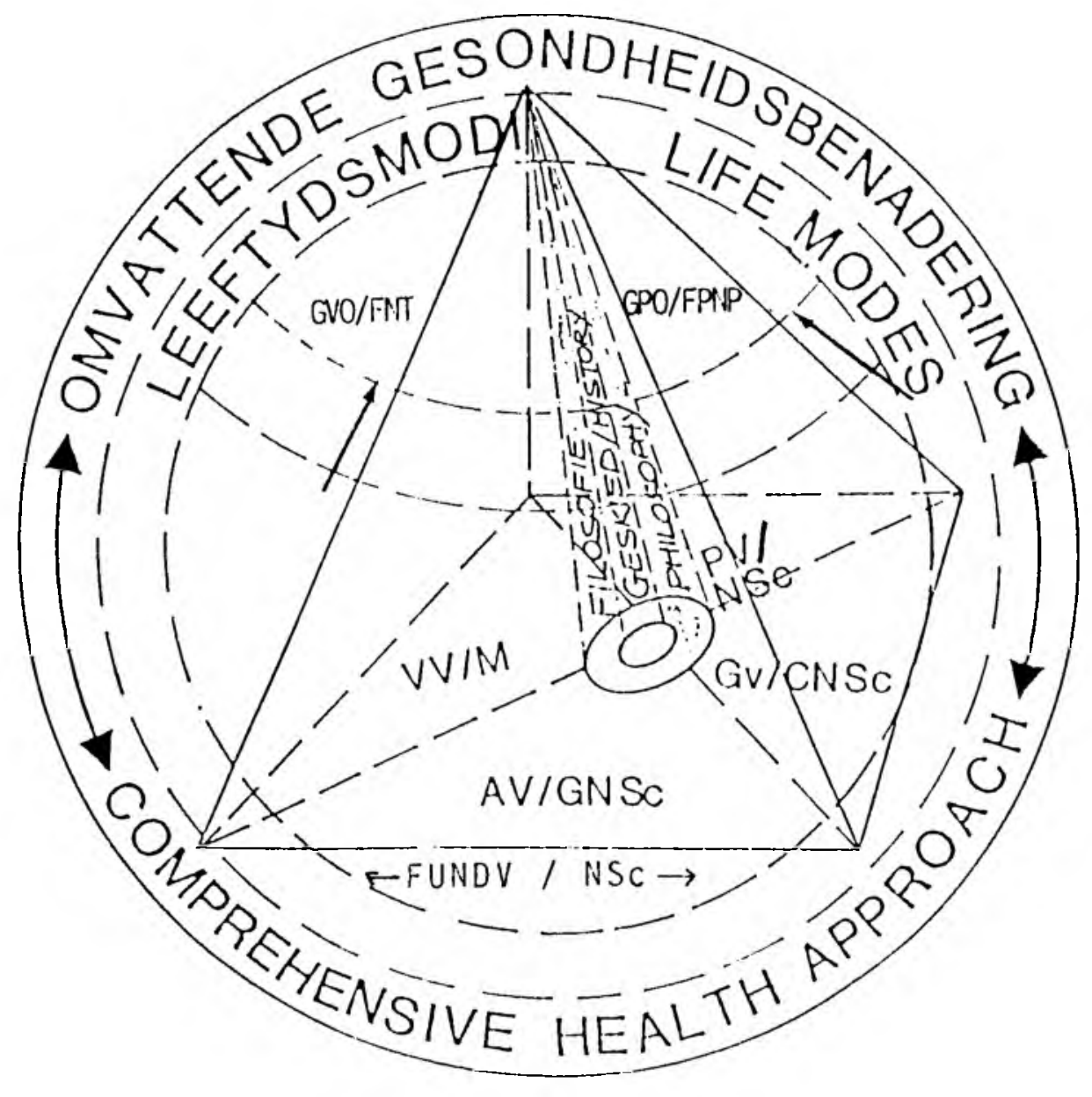

Community nursing science:

The history and philosophy of nursing as applied to this sub-discipline.

The preventive and promotive health needs of groups and communitics.

The influences of the environment and community characteristics on these health needs.

The structures, philosophies, systems,

economics, politics and aims of community health services.

The nursing approaches and techniques to address these problems.

The nursing assessment of communities and the planning, implementation and evaluation of community health programmes.

It is envisaged that these sub-disciplines in nursing become the basis of the organisation of the course content of basic nursing programmes, and that they also form the basis of post-basic and advanced nursing programmes.

Conceptualisation of the sub-disciplines of a special science is one of the important aspects of a philosophy for a special science. This development in nursing thinking in South Africa should form a solid foundation for further conceptualisation and debate. 